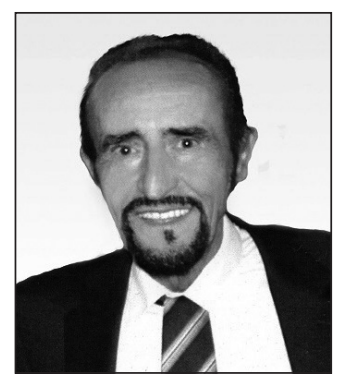

\title{
VÝŽIVA VČERA, DNES A ZAJTRA
}

Ladenie úvodníka podmieňujú dve významné udalosti: 16. októbra sme si pripomenuli Svetový deň výživy, ktorý bol tento rok určený významu optimálneho zloženia a spotreby potravín, a priamo s tým súvisiaci 3. kongres Slovenskej obezitologickej asociácie $\mathrm{v}$ dňoch 21.-23. októbra $\mathrm{v}$ Bratislave a $\mathrm{v}$ nadväznosti 4.-6. novembra 2021 kongres zameraný na chirurgiu obezity a metabolické poruchy v Prahe. Prvá udalost' sa týka interdisciplinárneho medicínskeho odboru hygiena výživy, ktorý sa podiel’a na riešení ochrany a podpory zdravia obyvatel’stva. Jeho dve základné bázy predstavujú fyziológia a patofyziológia výživy ludí a hygiena potravín, ktorá presadzuje diferencované zabezpečenie populácie nutrične plnohodnotnými i zdravotne bezpečnými potravinami. $V$ tradícii ešte z čias Československa to predstavujú vypracované odporúčané dávky spotreby potravín, ktoré vyjadrujú praktickú realizáciu fyziologických odporúčaných výživových dávok pre obyvatel'stvo ČR a SR. Disponujeme tak nielen dávkami potravín pre priemerného spotrebitel’a, ktoré sú významné z národohospodárskeho hl’adiska a umožňujú medzinárodné porovnania štandardov výživy, ale aj odporúčanými dávkami potravín pre predškolské a školské spoločné stravovanie, ako i pre výživu seniorov v domovoch sociálnej starostlivosti, vrátane zabezpečenia ich požiadaviek na liečebnú výživu.

Splnené sú tým požiadavky World Health Organization a Food and Agriculture Organization of the United Nations k Svetovému dňu výživy 2021, okrem iného zamerané aj na prevenciu viacerých degeneratívnych chorôb hromadného výskytu, ktoré vykazujú priamy vzt’ah k dysbalančnej výžive. Hlavným cielom hygieny výživy je vytvorenie obrazu o správnej výžive pre jednotlivé fyziologické skupiny obyvatel'stva. Považujem za potrebné vyjadrit' sa aj $\mathrm{k} \mathrm{v}$ súčasnosti často nesprávne používanému termínu alternatívnej výživy, ktorý možno použit' iba v prípade, ked' ide o nutrične rovnako plnohodnotný typ stravovania, porovnatelný s racionálnou výživou. Túto podmienku spíňa iba vegetariánske stravovanie, aj to len pre dospelého jedinca znalého princípov danej výživy, a v žiadnom prípade nie vegánska, makrobiotická alebo iné podobné formy výživy, ktoré ostávajú vzdialené od základných požiadaviek zdravej výživy. Nemožno ich preto akceptovat' ako trvalý spôsob výživy, snád’ iba na niekol'ko tzv. odl’ahčovacích dní.

Hlavný nástroj preventívnej medicíny predstavujú epidemiologické štúdie výživy, ktoré majú v Čechách i na Slovensku dlhú tradíciu. Jedny z prvých štúdií v Československu boli uskutočnené pracovníkmi endokrinologických ústavov v Prahe doc. Silinkom a spol. a v Bratislave doc. Podobom a spol. v povojnových rokoch 1949-1953. Riešili výskumnú úlohu zaoberajúcu sa výskytom endemickej strumy a endemických neuropsychických degenerácií (oligofrénie a kreténizmu) s určením ich výskytu a rizikových oblastí v súvislosti s nedostatkom jódu v strave. V Čechách bolo klinicky vyšetrených okolo 600-tisíc osôb a na Slovensku v 602 obciach 160-tisíc osôb oboch pohlaví a takmer všetkých vekových kategórií, čo je dnes nepredstavitel'ný rozsah štúdií.

Tieto štúdie priniesli prioritné poznatky a návrh prevencie strumy zavedením jodidácie kuchynskej soli v dávke $25 \mathrm{mg} / \mathrm{kg}$ soli. Docielilo sa tým vymiznutie endemickej strumy a kreténizmu v Československu. Výsledky týchto štúdií rezonovali nielen v európskom meradle, ale dosiahli až svetový význam.

Na začiatku 50. rokov minulého storočia sa uskutočnil aj prvý celoslovenský výskum výživy obyvatel'stva pracovníkmi Štátneho ústavu pre výživu l’udu a dietetiku v Bratislave (Budlovský, Sečanský a spol.). Sledovaný súbor tvorilo 10-tisíc klinicko-nutrične vyšetrených osôb a získané výsledky poukázali na značné regionálne rozdiely vo výžive obyvatel'stva a v niektorých prípadoch na ich zdravotne nepriaznivé dosahy.

Druhý reprezentatívny výskum výživy obyvatel’stva Slovenska sa uskutočnil v rokoch 1983-1989. Pracovníci Výskumného ústavu výživy ludu v Bratislave (Kajaba, Nagy a spol.) uskutočnili výskum, ktorý v dvoch etapách (jarný a jesenný výskum) poskytol výsledky klinického vyšetrenia 24-tisíc osôb oboch pohlaví, detí a dospelých a u vyše polovice uvedeného súboru sa uskutočnilo aj biochemické vyšetrenie. Cielene bol výskum zameraný i na zistenie prevalencie nekontagióznych chorôb v populácii, hlavne obezity a jej komplikácií, dyslipoproteinémií, diabetu 2. typu, artériovej hypertenzie a niektorých iných.

Na tohoročnom kongrese o obezite $\mathrm{v}$ Bratislave sa vo viacerých vystúpeniach potvrdil poznatok, že obézni ludia majú predispozíciu k horšiemu prekonávaniu covidu-19. Prejavuje sa t’ažším klinickým priebehom, častejšou potrebou umelej plúcnej ventilácie a, žial', i zvýšenou smrtnost’ou. Vyplýva z toho, že popri generácii seniorov a osôb s vážnejšími chronickými chorobami predstavujú aj obézni jedinci vo zvýšenej miere rizikovú skupinu populácie a mala by sa preto i u nich prednostne vykonat' vakcinácia proti koronavírusu SARS-CoV-2. Vyvstáva tým pre všetkých pracovníkov preventívnej medicíny aktuálna úloha edukovat' ludí o význame zdravého životného štýlu, prevencie obezity, ako aj vakcinácie, pretože táto predstavuje v súčasnosti hlavný nástroj zvládnutia pandémie spôsobenej novým koronavírusom SARS-CoV-2 a jeho mutáciami. 
V súčasnosti a blízkej budúcnosti by bolo žiaduce uskutočnit' viaceré štúdie v rámci hygieny výživy, napríklad výskum prevencie, profylaxie a liečby postkovidového syndrómu kvalitnou stravou s dostatočným zastúpením vítamínov D, C, E, K a stopových prvkov, hlavne zinku a selénu, a snád’ aj d’alšími nutraceutikami - flavonoidmi, antioxidačným tripeptidom glutationom a inými biogénnymi faktormi, ktoré by mohli priniest' cenné nové poznatky založené na evidence based medicine.

Doc. MUDr. Igo Kajaba, PhD. 